\title{
The Intervention Strategies To Reduce Tuberculosis Stigma In Community: A Systematic Review
}

\author{
Rezky Mulyana $^{1^{*}}$, Astuti Yuni Nursasi \\ ${ }^{1,2}$ Departement of Community Health Nursing, Faculty of Nursing, Universitas Indonesia, Depok, \\ West-Java 16424, Indonesia \\ ${ }^{2}$ Universitas Indonesia Hospital, Depok, West-Java 16424, Indonesia \\ *Corresponding email: rezkyners11@gmail.com
}

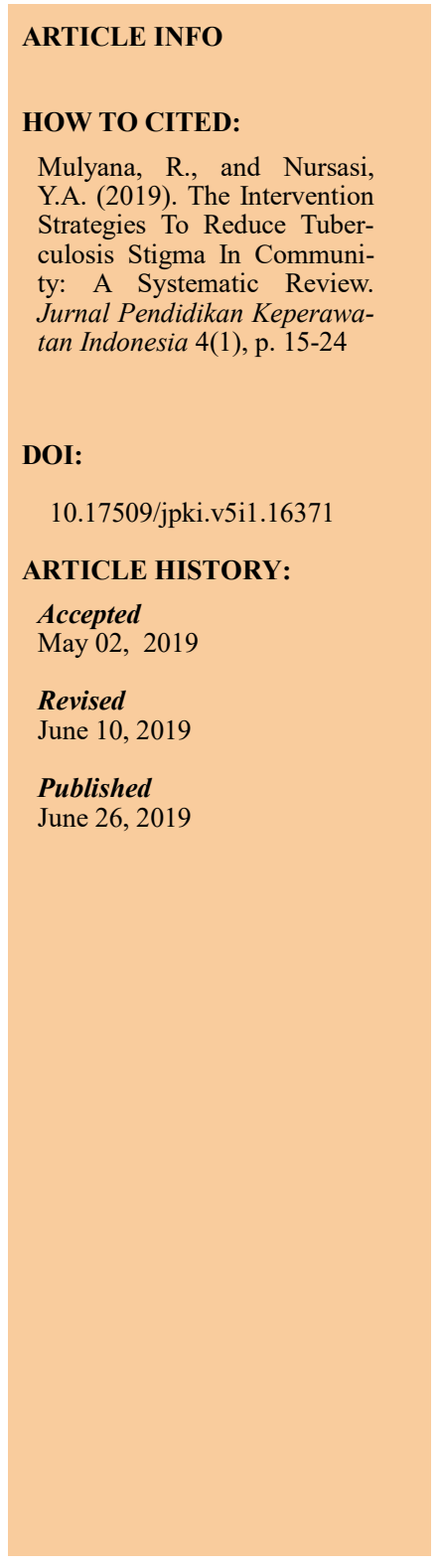

\section{A B S T R A K}

Stigma pada pasien tuberkulosis (TB) menyebabkan diskriminasi dan isolasi sosial yang berdampak pada upaya manajemen pengobatan TB. Tujuan dari literatur review ini untuk mengeksplorasi strategi intervensi di komunitas untuk mengurangi stigma tuberkulosis (TB). Desain menerapkan tinjauan sistematis. Data diambil dari database online Wiley Online Library, Science Direct, PubMed, Research Gate, Springer Link, Scopus, Google Cendekia, dan jurnal nasional pada periode 2008-2018. Pencarian artikel dalam sistematik review ini menerapkan kata kunci "Tuberkulosis" DAN "Stigma", "Mengurangi stigma", "Intervensi TB Stigma", "menangani stigma TB", "strategi untuk stigma TB". Eksplorasi dan pemilihan judul dan abstrak berdasarkan kriteria inklusi, dan mencari artikel dengan menyaring daftar referensi dalam kutipan dalam literatur untuk menjadi artikel tambahan. Hasil analisis penelitian menggunakan diagram alir PRISMA. Strategi intervensi untuk mengurangi stigma ditemukan empat strategi intervensi yaitu: (1) Pendidikan kesehatan, seperti meningkatkan pengetahuan tentang TB dan Kampanye TB, (2) Kunjungan Rumah, (3) Dukungan pasien TB seperti Komunitas, dukungan keluarga, dukungan sosial TB Club, dan dukungan keuangan, (4) Meningkatkan Kualitas pekerja kesehatan. Oleh karena itu, strategi intervensi untuk mengurangi stigma TB diperlukan dalam mengurangi stigma TB. Stigma TB yang rendah memiliki efek positif dalam mengendalikan dan eliminasi TB. Intervensi yang paling umum adalah dukungan pasien TB dan pendidikan kesehatan.

Kata Kunci: TBC; Stigma TB; Mengurangi stigma; Dukungan Pasien; Pendidikan kesehatan

\section{A B S T R A C T}

The stigma attached to tuberculosis (TB) patients leads to discrimination and social isolation, affecting the management of TB treatment. This literature review aims at exploring intervention strategy among communities to reduce tuberculosis (TB) stigma. The design employed was a systematic review. The data was obtained from Wiley Online Library database, Science Direct, PubMed, Research Gate, Springer Link, Scopus, Google Scholars, and national journals ranging from 2008-2018. Articles collected in this systematic review used "Tuberculosis" and "Stigma," "reducing stigma," "Intervention in TB Stigma," "dealing with TB stigma," "strategies for TB stigma" as the 
keywords. The title and abstract were explored and chosen based on inclusion criteria and additional articles selected by screening the list of references in citations from this literature. The result of the analysis is shown in the PRISMA flowchart. There were four intervention strategies found to reduce TB stigma, namely: (1) Health education, such as increasing TB socialization and campaign, (2) Home visit, (3) TB patients support, such as community support, family support, TB social club support, and finance support, (4) Improving medical workers quality. Therefor, some intervention strategies are required to reduce TB stigma. Low stigma has a positive impact on controlling and eliminating TB. The most common interventions are supports for TB patients and health education.

Keywords: TBC; TB stigma; reducing stigma; patient supports; health education

\section{INTRODUCTION}

Tuberculosis (TB) is an infectious disease caused by Mycobacterium tuberculosis. TB is spread through small spatter of sputum from patients with positive TB BTA (World Health Organization, 2018; Indonesia Ministry of Health, 2015). The prevalence of new TB case in Asia is $45 \%$, followed by Africa with $24 \%$ new cases. Cases of lung TB occur the most in 30 burden countries by $6.87 \%$ and eight countries with the newest TB cases out of total TB cases. India is the country with the most significant number of TB cases, followed by Indonesia, China, the Philippines, Pakistan, Nigeria, and South Africa (World Health Organization, 2018; Indonesia Ministry of Health, 2015). Prevalence of TB in Indonesia in 2016 was 10.4 million people with 1.2 million new cases every year, estimated 395 new cases per 100.000 people (World Health Organization, 2018).

Efforts to combat TB in Indonesia have been made for six decades; however, TB cases seem uncontrollable, and the uneven distribution leads to the gap among places in Indonesia (National Development Planning Agency, 2015). One of the strategies to control TB is by giving Directly Observed Treatment Short-Course (DOTS). The success level of TB treatment reduced TB cases from $87 \%$ in 2014 to $85 \%$ in 2016 (National Development Planning Agency, 2015). The decline of TB treatment success rate became an obstacle to overcome TB cases. It was caused by people stigma towards TB, resulting in a delay in treatment and access to the health service provider (Indonesia Ministry of
Health, 2015; Hidayati, 2015).

Stigma, according to Goffman, is defined as "an attribute which is deeply discrediting." It causes an individual to be classified differently than the rest due to different and bad moral status. Stigmatization refers to visible marks as results of physical expressions, such as disgust, discrimination, character defects, or marginal groups (Goffman, 1963; Baral, 2007). Accordingly, stigma is defined as a behavior which is discrediting individuals. Stigma affects social identity, which influences the ability to manage and to cure the disease (Craig, Daftary, Engel, Driscoll, \& Ioannaki, 2017). TB stigma is a great challenge for both patients and the global elimination of TB disease.

The stigma attached to TB patients means negative assumptions related to immoral behavior, immortality, hedonism, poverty, marginal groups, sex workers, and people with HIV/AIDS (Cremers et al., 2015; Sommerland, Wouters, Mitchell, et al., 2017). The effect of TB stigma leads to stigma internalization and belief on what other people think. The internalization process causes self-stigmatization that isolates tuberculosis patients from the social environment and hampers them from TB management (Cremers et al., 2015; Sommerland, Wouters, Mitchell, et al., 2017). Another study shows that half of the respondents $(50.4 \%)$ experienced stigmatization and stigma internalization caused by negative stereotypes from people, such as the association between HIV and TB.

Negative stereotypes cause TBC patients to feel distressed and worthless. Stigma internalization attached to TB patients stems from fear of 
TB transmission, desperation, guilt, and inferiority. Perception of TB as a punishment causes TB patients to isolate themselves (Chinouya \& Adeyanju, 2017; Cremers et al., 2015; Kurspahić -mujčić et al., 2013). Negative consequences of TB stigma are slander, insults, discrimination, and social isolation. TB stigma is likely to persist due to a lack of understanding about TB disease. Globally, TB stigma exists among people because they are afraid that they might be infected, causing people to isolate TB patients from their social function, even detain them from their household, caregivers, and health workers (Chakrabartty, Basu, Ali, Sarkar, \& Ghosh, 2018).

Intervention is needed in mitigating TB stigma since stigma is complex. Intervention focus on individuals, society, and policies at the same time is useful to reduce stigma. Moreover, intervention to mitigate discrimination and stigma should be based on the overall target population (Gronholm, Henderson, Deb, \& Thornicroft, 2017). Stigma intervention focusing on the society is done to shift people's attitude and perception by improving the search for help and compliance as well as empowering people to achieve their life goals (Collins, Wong, Cerully, Schultz, \& Eberhart, 2013; Hopwood, 2016).

An anti-stigma strategy has been categorized in the education field (replacing myth with accurate knowledge), contact or interaction with people to counter prejudice, and acts of protest to suppress stigmatization (Gronholm et al., 2017). Combination of contact with TB patients and education can reduce stigmatization. Moreover, psychoeducation intervention done by the family can help reduce stigmatization (Morgan, Villiers -tuthill, Barker, \& Mcgee, 2014). TB stigma mitigation is closely related to minimizing negative assumptions toward TB patients or helping to eliminate "stamps of shame" in society.

TB stigma reduction is an effort of diminishing bad image attached to TB patients, and disregarding worries, fear of insults and isolation from the people (Effendi, 2018; KNCV, 2016). Reducing TB stigma in the society is essential for TB patients so that they can get treatment, medication, as well as accomplish global TB management program by changing $\mathrm{TB}$ stigma into supports for TB patients (Craig et al., 2017). This literature review is presented to acknowledge the intervention strategy in order to minimize TB stigma in society.

\section{METHOD}

This study used a systematic review with a comprehensive literature search to obtain related articles, identify, and assess intervention strategy to reduce TB stigma in society. This systematic review included articles from 2008 to 2018 and used PRISMA flowchart (image 1). Data was obtained from Wiley Online Library, Science Direct, PubMed, Research Gate, Springer Link, Scopus, Google Scholar, and national journals ranging from 2008 to 2018 in both Indonesian and English. A relevant article reference list was searched to find additional articles in this systematic review. The authors conducted research selection in several phases, as follows:

1. Finding related articles by using "TB" and "stigma", "Reduce stigma", "TB Stigma Intervention", "tackling TB stigma", "strategy for TB stigma" as the keywords

2. Searching for articles and abstracts suitable with the inclusion criteria. Complete articles relevant to the inclusion criteria were taken as the main articles in this systematic literature review.

3. We are finding additional articles in the article citation reference list.

Reviews in the articles follow the research criteria. The inclusion criteria of this research area) research-based data, with experimental design and systematic review; b) articles are written in both Indonesian and English; c) articles published from 2008 to 2018 . These criteria were based on authors' consideration concerning stigma and discrimination towards HIV in 2004, as they also happen to people with TB. The authors are eager to see the right intervention to tackle TB stigma after it is a concern for four years, and its effectiveness in tackling TB stig$\mathrm{ma}$; d) this research focuses on some respondents, they are (a) community, (b) family with TB, and (c) people with TB. 
Mulyana, R., and Nursasi, Y.A.| The Intervention Strategies To Reduce Tuberculosis Stigma In Community...

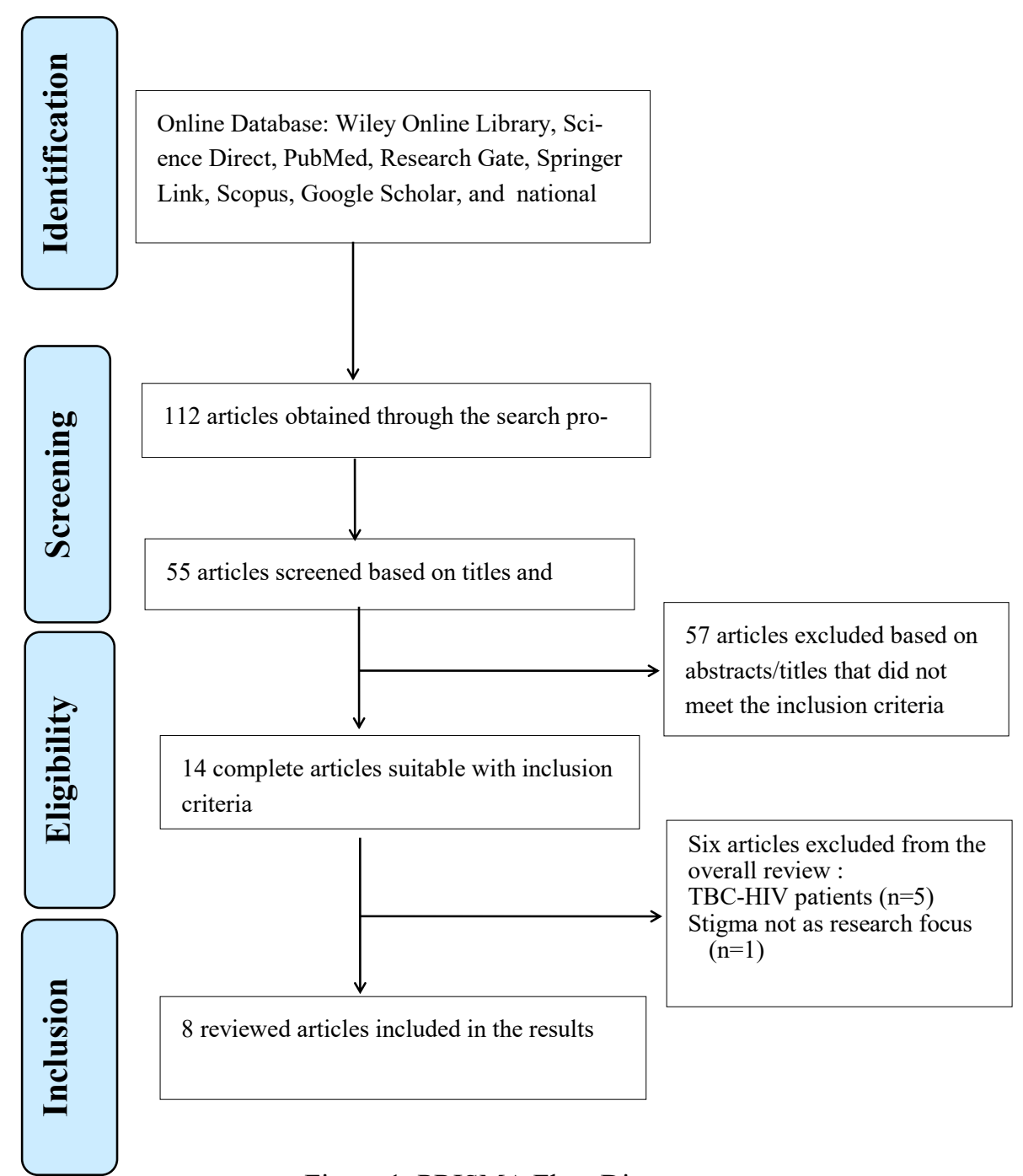

Figure 1. PRISMA Flow Diagram

Articles that did not suit the inclusion criteria were not reviewed. Excluded articles were those that did not provide intervention to tackle TB stigma and article construction without decent definition. The authors assessed the quality of study chosen according to the assessment instrument of Quality-Article Review, using the scale of Downs and Black (Health Evidence, 2016; Studies, 2008; Swedish Agency for Health Technology Assessment and Assessment of Social Services, 2016).

\section{RESULTS}

From the database, five articles were selected out of the total articles in both Indonesian and
English published from 2008 to 2018, using keywords concerning intervention to tackle stigma as the aim of this article. The result shows five studies identify intervention to tackle TB stigma. Four studies employed intervention study, and one employed a systematic review. Demography of the results is displayed in table 1. The results show that five studies indicate intervention to reduce TB stigma in the community. Four intervention strategies to tackle TB stigma following the research design were found. Details of the research design are displayed in table 2. Nearly half of the articles show that the intervention strategy to tackle TB is Health Education (table 2). 
Mulyana, R., and Nursasi, Y.A.| The Intervention Strategies To Reduce Tuberculosis Stigma In Community...

Table 1 Characteristic and Literature Review Interventions to Reduce TB Stigma $(n=5)$

\begin{tabular}{|c|c|c|c|c|c|}
\hline First Author & Year & Aim & Method & Participant & Outcome \\
\hline Hidayati & 2015 & $\begin{array}{l}\text { To identify the influence of education } \\
\text { to patients regarding TB transmission } \\
\text { to reduce stigma }\end{array}$ & $\begin{array}{l}\text { Pre- } \\
\text { experiment } \\
\text { with one } \\
\text { group doing } \\
\text { pre-test and } \\
\text { post-test }\end{array}$ & $\begin{array}{l}30 \text { respondents } \\
\text { selected using } \\
\text { an accidental } \\
\text { sampling meth- } \\
\text { od }\end{array}$ & $\begin{array}{l}\text { Health education can } \\
\text { provide knowledge and } \\
\text { reduce stigma. }\end{array}$ \\
\hline Macq & 2008 & $\begin{array}{l}\text { To compare the changes in internal- } \\
\text { ized stigma and TB treatment out- } \\
\text { come between TB group who got } \\
\text { intervention set, focusing on patients } \\
\text { who belong to the TB support group } \\
\text { with a home visit, and control groups } \\
\text { in rural Nicaragua. }\end{array}$ & $\begin{array}{l}\text { Intervention } \\
\text { study }\end{array}$ & $\begin{array}{l}122 \text { patients in } \\
\text { the intervention } \\
\text { group and } 146 \\
\text { in the control } \\
\text { group }\end{array}$ & $\begin{array}{l}\text { This study shows that } \\
\text { dealing with internal- } \\
\text { ized stigma, TB clubs, } \\
\text { and home visits were } \\
\text { sufficient to be imple- } \\
\text { mented. }\end{array}$ \\
\hline Rau & 2018 & $\begin{array}{l}\text { To fight stigma (1) scientifically eval- } \\
\text { uating the level and sources of stigma } \\
\text { about HIV and TB among healthcare } \\
\text { workers and (2) developing and test- } \\
\text { ing evidence-based intervention of } \\
\text { reducing stigma at general hospitals } \\
\text { in the Free State Province of South } \\
\text { Africa. }\end{array}$ & $\begin{array}{l}\text { Stratified } \\
\text { Cluster Ran- } \\
\text { domised } \\
\text { Control Trial } \\
\text { (RCT) }\end{array}$ & $\begin{array}{l}\text { Respondents of } \\
\text { this study were } \\
\text { healthcare } \\
\text { workers and all } \\
\text { staff working in } \\
\text { the hospital }\end{array}$ & $\begin{array}{l}\text { Training agents of } \\
\text { change, healthcare } \\
\text { workers, and social } \\
\text { campaign. }\end{array}$ \\
\hline $\begin{array}{l}\text { Sommerland } \\
\text { Yin }\end{array}$ & 2017 & $\begin{array}{l}\text { To assess the effectiveness of inter- } \\
\text { ventions aimed at reducing TB stigma } \\
\text { in patients, health care workers, and } \\
\text { the general community. }\end{array}$ & $\begin{array}{l}\text { Systematic } \\
\text { Review }\end{array}$ & $\begin{array}{l}\text { Seven studies } \\
\text { were identified } \\
\text { as providing } \\
\text { quantitative ( } \mathrm{n} \\
=4) \text { or qualita- } \\
\text { tive }(\mathrm{n}=3) \\
\text { evidence of } \\
\text { effectiveness }\end{array}$ & $\begin{array}{l}\text { Knowledge-shaping } \\
\text { and attitude-changing } \\
\text { interventions aimed at } \\
\text { the public, patients and } \\
\text { their families were } \\
\text { effective in reducing } \\
\text { anticipated stigma }\end{array}$ \\
\hline Yin & 2017 & $\begin{array}{l}\text { To evaluate the status of TB-related } \\
\text { stigma and its associated factors } \\
\text { among TB patients in China. }\end{array}$ & $\begin{array}{l}\text { Cross- } \\
\text { Sectional } \\
\text { study }\end{array}$ & $\begin{array}{l}1342 \text { TB pa- } \\
\text { tients were } \\
\text { recruited from } \\
\text { TB dispensaries } \\
\text { in three coun- } \\
\text { ties in Hubei } \\
\text { Province using } \\
\text { a multi-stage } \\
\text { sampling meth- } \\
\text { od }\end{array}$ & $\begin{array}{l}\text { Interventions concen- } \\
\text { trating on reducing TB } \\
\text { patients' stigma in Chi- } \\
\text { na should focus on } \\
\text { improving patients' } \\
\text { family function and } \\
\text { patients' knowledge } \\
\text { about TB. }\end{array}$ \\
\hline
\end{tabular}

Table 2 Intervention Strategies to Reduce TB Stigma $(n=5)$

\begin{tabular}{|c|c|c|c|c|c|c|}
\hline \multirow[b]{2}{*}{ Intervention } & \multirow[b]{2}{*}{ Review } & \multicolumn{3}{|c|}{ Quantitative } & \multirow[b]{2}{*}{ Total } & \multirow[b]{2}{*}{$\%$} \\
\hline & & $\begin{array}{c}\text { Cross- } \\
\text { Sectional }\end{array}$ & $\begin{array}{c}\text { Quasi- } \\
\text { Experiment }\end{array}$ & $\mathrm{RCT}$ & & \\
\hline Health education & 1 & 2 & - & - & 3 & 60 \\
\hline Home Visit & 1 & - & 1 & - & 2 & 40 \\
\hline TB Patients Support & 1 & - & 1 & - & 2 & 40 \\
\hline $\begin{array}{l}\text { Enhancing Qualities } \\
\text { of health worker }\end{array}$ & - & - & - & 1 & 1 & 20 \\
\hline
\end{tabular}


One of the studies shows an increase in education, from $18.93 \%$ to $26.00 \%$. Health education can reduce stigma to a low level $(\mathrm{p}<$ 0.001). Health education concerning TB stigma can educate people as well as reduce TB stigma since some people are still not well-informed about TB. Three studies in this literature review show one effective intervention strategy to reduce TB stigma, which is by giving health education to TB patients, family, health workers, and society as an attempt to raise awareness (Hidayati, 2015; Misir, 2013; Royce et al., 2017).

Meanwhile, other studies that explore the correlation between TB patients' knowledge and stigma attached to them find that they have a significant influence on the level of the stigma (Yin et al., 2017). These studies show that there is a correlation between the state of being lessinformed about TB and higher TB stigma score, which is 4.86 out of 8 . Patients' knowledge on TB, such as recovery, symptoms, and spread, has a significant influence on the level of stigma ( $\beta=-0.18, P=0,0025)$ (Yin et al., 2017).

Another study shows that intervention strategies to reduce TB stigma are in forms of a home visit, TB club, counseling, attitude change, TB campaign, and health workers quality improvement (Macq, Solis, Martinez, \& Martiny, 2008; Tadesse, 2016; Wynne, 2012). Patients manage the stigma attached to them with the help and support from others such as family support, social support, and financial support in order to reduce TB stigma (Macq et al., 2008; Sommerland, Wouters, Masquillier, et al., 2017). Supports can improve competent individual coping in preventing the adverse effects of stress as a result of stigma in one domain while causing more damage in another domain (Frost, 2011). Another study shows a lower APGAR score $(B=$ $-0,29, \mathrm{P}<0,0001)$ about increasing level of stigma (Yin et al., 2017).

Intervention to improve medical care quality is the protection of agents of change in health care workers. The research results involved measuring the level of stigma concerning TB and HIV among community health care in Free State Province in South Africa and generating information regarding the sources of stigma and evidence-based stigma study, with evidence provided. Interventions were developed and played in randomly selected general hospitals in Free State Province, South Africa (Rau et al., 2018).

\section{DISCUSSIONS}

This section covers the result of a systematic review of interventions to reduce TB stigma. Overall, intervention strategies can be implemented to reduce TB stigma in society. The internalized stigma that becomes a significant predictor is a discrimination component. Stigma related to social power, finance, and supports. TB stigma includes negative stereotypes, prejudice, and discrimination (Moriarty et al., 2012). The results of review article showed there are four strategies to reduce TB stigma, such as a) Health education; b) Home Visit; c) TB Patients support; d) Enhancing Qualities of health worker

\section{Health Education}

The results of the review article showed there are participants demonstrated low levels of knowledge and awareness and held many misconceptions about TB. This study support by other studies that show health education and information should be paramount when caring for the patient and mass media campaigns and interventions for target groups in terms of stigmarelated knowledge and attitudes have a positive impact (Yin et al., 2017; Macq et al., 2008). When Media showed TB as a contagious disease which is fearful. The information due to the fear of the ailment and reinforces the stigma in society (Tadesse, 2016). The misconception in TB patients is regarding transmission, prevention, and treatment of TB. There are becomes a gap that causes community level misinformation and lack of understanding about TB.

This study corroborates other studies that indicate health education and information should be prioritized when dealing with patients, delivering the campaign in mass media, and doing an intervention for target groups regarding knowledge related to stigma and positive attitude $(25,27)$. Currently, the media portray TB as 
a terrifying contagious disease. It is due to the fear of the disease that strengthens the stigma within society (Tadasse, 2016). Misunderstanding towards $\mathrm{TB}$ patients is mostly related to transmission, prevention, and recovery. There were becomes a gap that causes misinformation and misunderstanding within the community.

Moreover, this study lends support to other studies that suggest the implementation of a public information campaign. This perhaps may tackle stigma and improve health results since there is much information that is not directly explained in lower stigma so that individuals with relatively more specific knowledge about TB are possible to stigmatize TB compared to individuals who cannot identify TB information (Cohen, Ewing, Eakin, Sterling, \& Zechmeister, 2018).

\section{Home Visit}

Health education and home visit can reduce TB stigma. In this study, a home visit (40\%) is proven to reduce TB stigma. This study is in line with other studies indicating that home visit can significantly reduce TB stigma since it can make TB patients feel more empowered to interact with the community (Macq et al., 2008). A home visit can be an alternative to support TB patients. The support should involve patients, family, and their social environment because patients with the contagious disease need more social support (Sharma, Joshi, \& Kumar, 2017).

This study is following experimental research design indicating regular home visits improve and stabilize patients' condition as well as the communicative ability to interact with family members, social skills, and emotional support (Cheng, Huang, Lin, Wang, \& Yeh, 2018). Home visits made TB clients for sharing their stigma experience and for finding solutions to reduce stigma in the community and to improve positive perceptions of TB (International HIV/ AIDS Alliance, 2011).

\section{TB Patients Support}

The third result of this study is a support in the form of TB support group. There were supported by other studies indicating TB patients that belong to a TB support group are not affected by the TB stigma. TB support group can mitigate negative attitude and social isolation because the environment is distinct and accepted to them (Courtwright, 2010). Another study conducted in Nicaragua shows that interventions of the TB support group and home visit have significantly plummeted in reducing stigma (Sermrittirong, n.d.). Intervention strategies to reduce stigma are still insufficient.

Support groups have been recommended to reduce stigma since contacts with others will overcome the interpersonal discrepancy, initiating positive interaction and relationship between support groups that raise self-esteem (National Academy of Sciences, Engineering, 2016). TB patients support help clients to talk about their TB stigma experience. The support group members carrying out several stigma awareness and make TB patients be more accepting of community perspective about $\mathrm{TB}$, and there was less gossiping ( International HIV/AIDS Alliance, 2011).

\section{Enhancing Qualities of Health Worker}

Stigma does not only come from patients or the community but also healthcare workers. This study shows that public healthcare workers develop intervention concerning stigma. Also, it generalizes information on stigma sources (Rau et al., 2018). Another study that supports this analysis indicates an improvement in healthcare quality regarding TB stigma, including knowledge and delivery skills in dealing with fear-based stigma. Educating people who interact with TB patients surely helps reducing stigma (Nyblade, Stangl, Weiss, \& Ashburn, 2009).

Enhancing the quality of health workers is carried out by conducting program training to improve the knowledge and skills to reduce stigma in the community. Integrate stigma training is not a barrier to employees accessing information and services, develop workplace policies that address stigma and discrimination. Reducing stigma can improve productivity through improved health of employees that will support how to reduce stigma can save money and increase profits and become role models to reduce 
the stigma and rectify the negative perceptions that have been inherent in a community (International HIV/AIDS Alliance, 2011).

Several limitations should be considered in the article. Firstly, this study did not integrate qualitative result using meta-synthetic. Secondly, this study encounters limitation in the synthetic accuracy of all current findings that data extraction process can result in bias. The data may consequently cause unreported insignificant findings. Thirdly, the data is mostly explorative so that this study cannot put types of interventions into groups of types of stigma and intervention objectives, both self-stigma and social stigma.

Moreover, there is an absence of criteria quality applied in the form of a percentage of the total score that may indicate quality. The score of the quality assessment tool is 8 (Health Evidence, 2016; Studies, 2008; Swedish Agency for Health Technology Assessment and Assessment of Social Services, 2016). As for intervention study, scores of Downs and Black range from 7 to 22 (Health Evidence, 2016; Studies, 2008; Swedish Agency for Health Technology Assessment and Assessment of Social Services, 2016).

\section{CONCLUSION}

TB stigma is something that affects the objective of TB global. Intervention strategies to

\section{REFERENCE}

Bappenas. (2015). Laporan Pencapaian Tujuan Pembangunan Milenium di Indonesia 2014.

Baral, S. C., Karki, D. K., \& Newell, J. N. (2007). Causes of stigma and discrimination associated with tuberculosis in Nepal: a qualitative study. BMC Public Health, vol.7, no.211, 1-10. https://doi.org/10.1186/14712458-7-211

Chakrabartty, A., Basu, P., Ali, K. M., Sarkar, A. K., \& Ghosh, D. (2018). Tuberculosisrelated stigma and its effect on the delay for sputum examination under the Revised $\mathrm{Na}$ tional Tuberculosis Control Program in In- reduce TB stigma are important since managing and eliminating TB are the objective of the development. Based on this article, several interventions can reduce TB stigma within society. The required intervention strategy to reduce TB is health education. Health education can help provide more information regarding TB in society that can diminish misunderstandings about TB by delivering the lack information on TB as this information helps people to change their attitude and create a positive image of TB patients. Health education will make the process of anticipating stereotypes, tackling negative stereotypes, and tackling discrimination towards TB patients easier.

\section{Conflict of interests}

The authors have no conflict of interests to declare

\section{Acknowledgment}

The authors would like to extend their gratitude to Indonesia Endowment Fund for Education (LPDP) that has funded the author's magister program. dia. Indian Journal of Tuberculosis, 65(2), 145-151. https://doi.org/10.1016/ j.ijtb.2017.08.032

Cheng, J., Huang, X., Lin, M., Wang, Y., \& Yeh, T. (2018). A mental health home visit service partnership intervention on improving patients' satisfaction. Archives of Psychiatric Nursing, 32(4), 610-616. https:// doi.org/10.1016/j.apnu.2018.03.010

Chinouya, M. J., \& Adeyanju, O. (2017). A disease called stigma: the experience of stigma among African men with TB diagnosis in London. Public Health, 145, 45-50. https://doi.org/10.1016/j.puhe.2016.12.017

Cohen, M. J., Ewing, H., Eakin, M., Sterling, T., 
\& Zechmeister, E. J. (2018). Blaming the Victim: Knowledge of Tuberculosis is Associated with Greater Stigma in Brazil.

Collins, R. L., Wong, E. C., Cerully, J. L., Schultz, D., \& Eberhart, N. K. (2013). Interventions to Reduce Mental Health Stigma and Discrimination _ RAND.

Courtwright, A. (2010). Tuberculosis and Stigmatization: Pathways and Interventions. Public Health Report, 125, 34-42.

Craig, G. M., Daftary, A., Engel, N., Driscoll, S. O., \& Ioannaki, A. (2017). International Journal of Infectious Diseases Tuberculosis stigma as a social determinant of health : a systematic mapping review of research in low incidence countries. International Journal of Infectious Diseases, 56, 90-100. https://doi.org/10.1016/j.ijid.2016.10.011

Cremers AL, de Laat MM, Kapata N, Gerrets R, Klipstein-Grobusch K, Grobusch MP (2015) Assessing the Consequences of Stigma for Tuberculosis Patients in Urban Zambia. PLOS ONE 10(3): e0119861. p. 1-16. https:// doi.org/10.1371/journal.pone.0119861

Effendi, W. I. (2018). Tuberkulosis dan Stigma.

Frost, D. M. (2011). (Frost, 2011) Social stigma and its consequences for the socially stimatized.pdf, 11, 824-839. Social and Personality Psychology Compass, 5(11). https:// doi.org/10.1111/j.1751-9004.2011.00394.x Social

Goffman, E. (1963). Goffman, Erving(1963) Stigma. London: Penguin. Stigma: Notes on the Management of Spoiled Identity. London: Penguin Group.

Gronholm, P. C., Henderson, C., Deb, T., \& Thornicroft, G. (2017). Interventions to reduce discrimination and stigma: the state of the art. Social Psychiatry and Psychiatric Epidemiology, 52(3), 249-258. https:// doi.org/10.1007/s00127-017-1341-9

Health Evidence. (2016). Quality Assessment Tool - Review Articles.

Hidayati, E. (2015). Pengetahuan dan stigma masyarakat terhadap TBC setelah diberikan pendidikan kesehatan mengenai penegahan dan penularan. Prevention, 2(1), 17-23.

Hopwood, M. (2016). Interventions to reduce
Art \& Social Science Centre For Social Research in Health, (August).

International HIV/AIDS Alliance. 2011. Integrating stigma reduction into HIV programming: Lessons from the Africa Regional Stigma Training Programme. Alliance.

Kementerian Kesehatan RI. (2015). InfoDatin. InfoDatin. https://doi.org/24442-7659

KNCV. (2016). Annual report 2016 (Vol. 31).

Kurspahić-mujčić, A., Hasanović, A., \& Sivić, S. (2013). Tuberculosis-related stigma and delay in seeking care after the onset of symptoms associated with tuberculosis, 10 (April), 272-277.

Macq, J., Solis, A., Martinez, G., \& Martiny, P. (2008). Tackling tuberculosis patients ' internalized social stigma through patientcentered care: An intervention study in rural Nicaragua, BMC Public Health 8(154), 110. https://doi.org/10.1186/1471-2458-8-154

Misir, P. (2013). HIV / A IDS stigma-reduction on VCT uptake: An adapted systematic review, 18, 150-164.

Morgan, K., Villiers-tuthill, A., Barker, M., \& Mcgee, H. (2014). The contribution of illness perception to psychological distress in heart failure patients, 1-9.

Moriarty, A., Jolley, S., Callanan, M. M., \& Garety, P. (2012). Understanding reduced activity in psychosis : the roles of stigma and illness appraisals, 1685-1693. Social Psychiatry and Psychiatric Epidemiology 47(10), p. 1685-1693. https://doi.org/10.1007/ s00127-012-0475-z

National Academies of Sciences, Engineering, and M. (2016). Ending discrimination against people with mental and substance use disorders: The evidence for stigma change. United State of America. https:// doi.org/10.17226/23442

Nyblade, L., Stangl, A., Weiss, E., \& Ashburn, K. (2009). Combating HIV stigma in health care settings: what works? Journal of the International AIDS Society, 7. https:// doi.org/10.1186/1758-2652-12-15

Rau, A., Wouters, E., Engelbrecht, M., Masquillier, C., Uebel, K., \& Kigozi, G. (2018). Towards a health-enabling working environ- 
healthcare workers in the Free State, South Africa: study protocol for a randomized controlled trial, 1-15.

Royce, R. A., Colson, P. W., Woodsong, C., Swinson-Evans, T., Walton, W., Maiuri, A., Royce, R. A. (2017). Tuberculosis Knowledge, Awareness, and Stigma Among African-Americans in Three Southeastern Counties in the USA : a Qualitative Study of Community Perspectives. Journal of Racial and Ethnic Health Disparities, 47-58. https://doi.org/10.1007/s40615-015-0200-1

Sermrittirong, S. (n.d.). Stigma and stigma interventions related to leprosy and tuberculosis in Thailand.

Sharma, D., Joshi, A., \& Kumar, P. (2017). Stigma and Psychological Problems Encountered By People with Leprosy and How Counselling Helps: A Systematic Review The international journal of Indian psychology 4(4), p. 176-186. https:// doi.org/10.25215/0404.039

Sommerland, N., Wouters, E., Masquillier, C., Engelbrecht, M., Kigozi, G., Uebel, K., Rau, A. (2017). Stigma as a barrier to the use of occupational health units for tuberculosis services in South Africa. The International Journal of Tuberculosis and Lung Disease, 21(11), 75-80. https://doi.org/10.5588/ ijtld.17.0030
Sommerland, N., Wouters, E., Mitchell, E. M. H., Ngicho, M., Redwood, L., Masquillier, C., Van Rie, A. (2017). Evidence-based interventions to reduce tuberculosis stigma: a systematic review. The International Journal of Tuberculosis and Lung Disease, 21(11), 81-86. https://doi.org/10.5588/ijtld.16.0788

Studies, A. T. (2008). Downs and black checklist.

Swedish Agency for Health Technology Assessment and Assessment of Social Services. (2016). Evaluation and synthesis of studies using qualitative methods of analysis Swedish agency for health technology assessment and assessment of social services.

Tadesse, S. (2016). Stigma against tuberculosis patients in Addis Ababa, Ethiopia. PLoS ONE, 11(4), 1-11. https://doi.org/10.1371/ journal.pone. 0152900

Tuberculosis. (n.d.).

Wynne, A. (2012). TB, HIV and TB/HIV coinfection: Community Knowledge and Stigma in Western Uganda.

Yin, X., Yan, S., Tong, Y., Peng, X., Yang, T., Lu, Z., \& Gong, Y. (2017). Status of tuberculosis-related stigma and associated factros: a cross-sectional study in central China. 